\title{
From the Boom to the Collapse: a Technical Efficiency Analysis of the Spanish Construction Industry during the Financial Crisis
}

\author{
Xosé Luís Fernández-López and Pablo Coto-Millán \\ University of Cantabria, Spain
}

\begin{abstract}
Despite its contribution to the Spanish economy, as far as the authors are aware, the technical efficiency of the Spanish construction industry has neither been measured nor have the factors influencing it been analyzed. This paper measures the technical efficiency of the Spanish construction sector before and during the current financial crisis and investigates the degree to which factors influencing efficiency levels in this sector have changed. Stochastic frontier analysis (SFA) methods are applied to firm-level data (692 constructions firms) over the period 19962011. The results show that the average Technical Efficiency of the sector is 0.85. Results also indicate that variables affecting Technical Efficiency in the construction sector must be analyzed depending on real state cycle. Based on the findings, policy recommendations to improve the sector efficiency were developed.

Important factors affecting efficiency change have been identified, and some managerial recommendations to increase the sector efficiency have been developed. The main recommendations for construction companies include: (1) cooperation and company mergers have a positive impact on companies' efficiency; (2) accumulation of excessive financial burden damages the business long-term stability; and (3) business strategy should be tailored to economic prospects.
\end{abstract}

Keywords: Technical efficiency, the construction industry, Spain, stochastic frontier analysis.

Paper Type: Viewpoint

\section{Introduction}

Construction is unusually complex, given that every project in construction is unique. The product developed is consequently heterogeneous; it can vary from a simple home renovation, the construction of new houses and to the execution of a large hydraulic work, an airport, a hospital, etc. As such there are challenges to measuring the quality of construction projects, as well as quantifying the real economic figures of a firm/the sector.

Horta et al. (2013) described buildings, heavy civil and specialty trade as the main construction activities. Construction companies specialize in activities that report a higher return on investments. In the Spanish case, in recent years, the sector has concentrated on real estate activities. Looking a little more closely into the field of building activities, we will find ourselves in the common phenomenon of real estate bubble formation. The bubble is linked to three

Copyright: Construction Economics and Building 2015. (C) 2015 Xosé Luís Fernández-López and Pablo Coto-Millán. This is an Open Access article distributed under the terms of the Creative Commons Attribution 4.0 Unported (CC BY 4.0) License (https://creativecommons.org/licenses/by/4.0/), allowing third parties to copy and redistribute the material in any medium or format and to remix, transform, and build upon the material for any purpose, even commercially, provided the original work is properly cited and states its license.

Citation: Fernández-López, X.L and Coto-Millán, P., 2015. From the Boom to the Collapse: a Technical Efficiency Analysis of the Spanish Construction Industry during the Financial Crisis, Construction Economics and Building, 15(1), 104-117. DOI: http://dx.doi.org/10.5130/ajceb.v15i1.4168 
intrinsic characteristics of real estate activities: rigid supply in the short term, the important role of expectations for supply and demand, and high leverage on production and home purchase.

Shiller (2008) argued that the most important single element in the house price boom is, as he puts it, the social contagion of boom thinking ${ }^{1}$. This is one of the reasons why during the decade 1996-2007 Spain featured in the formation of a real estate bubble. The Spanish construction sector enjoyed a period of constant growth reaching a 12.1\% share of gross value in 2006, which is twice the overall comparable figure for the EU (Eurostat). According to Kapelko et al. (2014), until 2007 Spain was recording higher annual new home construction completions than France, Germany and Italy combined. However we should note that the formation of a real estate bubble has not been just a Spanish issue, and the United States, UK, Ireland, South Africa, and China among others, have been affected by this phenomenon. But Spain is indisputably one of the countries most affected after the burst of the housing bubble. Figure 1 presents the pattern of construction permits granted between 1990 and 2011. A significant growth in construction permits granted was observed since 1996, reaching a peak in 2006. Since 2007, construction permits granted plummets. As an example, construction permits granted in 2011 only account for $14 \%$ of those issued in 2006.

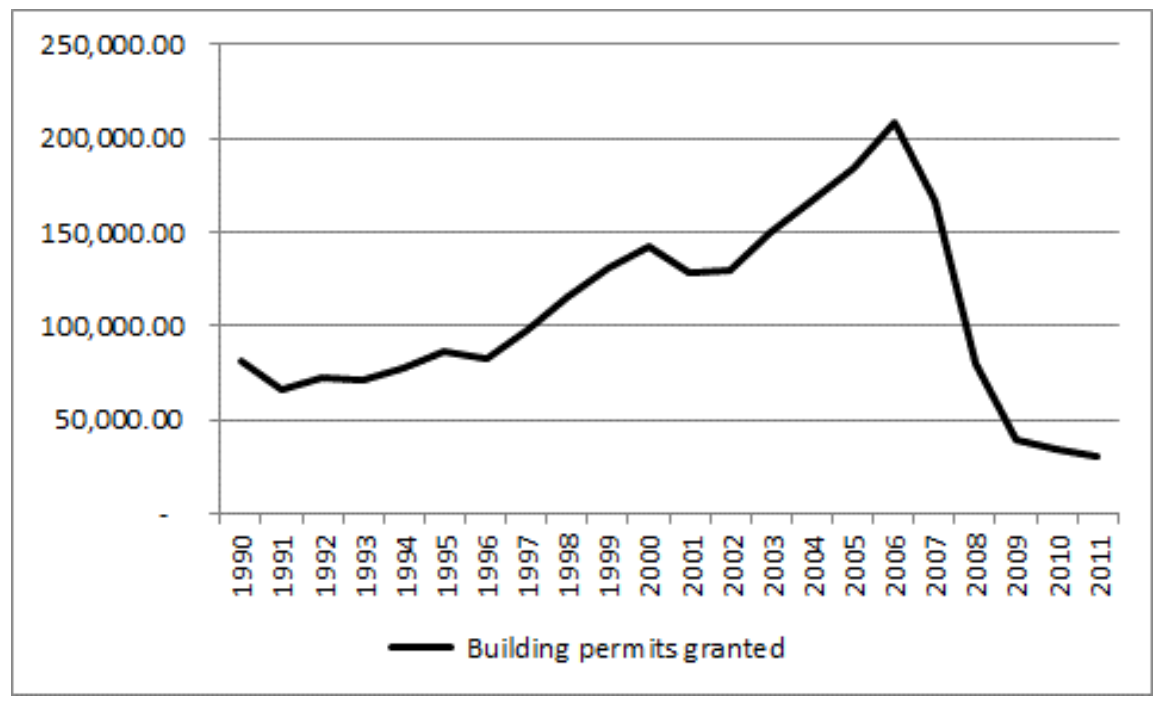

Figure 1: Spain, construction permits granted (number) 1990-2011.

(Source: elaborated based on the information from the Spanish Statistical Office)

Unleashed in 2007 by the U.S. subprime turmoil, the financial crisis unfolded at a speed and magnitude even the most die-hard pessimists could not have predicted. Fuelled by the high level of financial leverage, the financial constraints placed the Spanish construction sector in a more adverse situation than other sectors of the national economy, causing the wholesale collapse of the industry. A growing number of bankruptcies among Spanish construction firms, including some major construction firms such as Astroc Mediterraneo, Martinsa-Fadesa, Habitat, and most recently Reyal Urbis, hit the sector hard.

\footnotetext{
${ }^{1}$ Gimeno and Martínez-Carrascal (2010) provide macroeconomic evidence in support of this effect using Spanish data.
} 
In spite of the positive contribution to the Spanish economy, the Technical Efficiency (hereinafter TE) of the Spanish construction industry has neither been measured, nor have the factors influencing the efficiency been analyzed. Given these notable shortcomings in the field of construction at domestic level as well as international level, this paper aims to contribute to economic literature in two aspects:

- Estimating the technical efficiency of the Spanish construction sector through Stochastic Frontier Analysis (SFA) techniques.

- Identifying the factors that are impacting the efficiency of construction companies, particularly in crisis settings. A better understanding of the factors affecting sector efficiency will lead the industry to improve its response to future economic instabilities.

\section{Literature Review}

\section{Technical Efficiency (TE)}

The TE of a production may be defined as the ability of a firm to produce as much output as possible, given certain levels of inputs or factors of production and certain technology. Farrell (1957) suggested a method of measuring the TE of a firm in an industry, by estimating the production function of firms which are "fully-efficient". Many subsequent papers have applied and reviewed Farrell's ideas. The TE literature can be divided into two principal groups according to the method chosen to estimate the frontier production function: deterministic frontier and stochastic frontier. Debate continues over which approach is the most appropriate one to use.

On one hand we have the Data Envelopment Analysis (DEA) that is a deterministic and nonparametric approach - it does not require any assumption about the functional form of the production or cost frontier introduced by Charnes, Cooper and Rhodes (1978) to measure efficiency under the assumption of constant returns to scale, and extended by Banker, Charnes and Cooper (1984) to allow variable returns to scale. Ruggiero (2007) demonstrates that the major advantages of the DEA approach are its nonparametric nature and its ability to handle multiple outputs and multiple inputs. On the DEA down side, econometricians have argued that the approach produces biased estimates in the presence of measurement error and other statistical noise. Deterministic approaches are based on cross-sectional models; however, as Ruggiero (2004) argued, they can be extended to panel data models by averaging the data across time.

On the other hand, we have the stochastic production frontier. This approach is motivated by the idea that deviations from the production 'frontier' might not be entirely under the firm's control. Under the interpretation of the deterministic frontier, for example, an unusually high number of random equipment failures, or even bad weather, might ultimately appear, to the analyst, as inefficiency.

Since Aigner, Lovell and Schmidt (1977) proposed their pioneer work, both the theoretical development and empirical application of stochastic frontier models have prospered in the literature. Stevenson (1980) introduced the 'Truncated Normal Model' arguing that the zero mean assumed in the Aigner, Lovell and Schmidt (1977) model was an unnecessary restriction. Panel data applications have kept pace with other types of developments in the literature. Pitt and Lee (1981), Kumbhakar's (1990), Lee and Schmidt (1993), Battese and Coelli (1992) suggested different Stochastic Panel Data Models. The debate on whether to use a one-step or two-step approach introduced important developments into the investigation of how exogenous factors influence the one-sided inefficiency effect. The extensive Monte Carlo results presented by Wang 
and Schmidt (2002) favor the one-step approach. Among the different models developed, perhaps the most well-known model of the one-step approach is the Battese and Coelli (1995) model. These authors propose parameterizing the mean of the pre-truncated distribution as a way to study the exogenous influence on inefficiency.

Heterogeneity was another topic of discussion among researchers. Greene (2005a) categorizes heterogeneity between observable and unobservable heterogeneity. In Orea and Kumbhakar (2004) and Greene (2005b), a latent class specification is suggested to accommodate heterogeneity across firms in the sample.

Recent research work has tried to combine the strengths of the stochastic method into DEA Models. As an example Simar and Zelenyuk (2011) integrate a stochastic SFA-style noise term to the nonparametric, axiomatic DEA-style cost frontier.

\section{Efficiency, Crisis and the Construction Industry}

Construction has received much less attention in economic literature than other sectors of the economy. There are very few studies analysing the efficiency of the construction sector and, to the best of our knowledge, there is just one, You and $\mathrm{Zi} \mathrm{(2007),} \mathrm{approximating} \mathrm{the} \mathrm{effect} \mathrm{of} \mathrm{an}$ economic crisis on the efficiency of the construction industry. Globally, country studies focused on the whole construction sector, report a wide range of efficiency levels from a low of around $50 \%$ for Canadian firms (Pilateris and McCabe, 2003), approximately 60\% for Portuguese firms (Horta, Camanho and Moreira da Costa, 2012), to higher estimates of 83\% for Norwegian firms (Edvardsen, 2004), 84\% for Chinese firms (Zheng, Chau and Hui, 2011) and 93\% for Greek firms (Tsolas, 2011).

Regarding the factors which affect efficiency determinants, Chau and Wang (2003) used the DEA method to evaluate the efficiency of construction firms in Hong Kong. The results showed that (i) larger firms could produce more efficiency than smaller firms, (ii) companies used mechanization to improve the growth efficiency, and (iii) companies used subcontracting and outsourcing to improve productivity efficiency. Sueyoshi and Goto (2009) used the DEA method to evaluate the construction industry policies in Japan. The research indicated that Japanese construction companies have high amounts of labour and that the industry was the main support to local economy. Li et al. (2013) find that the efficiency of Hong Kong contractors is associated with their managerial ability to control business costs and financial ability to manage both short-term and long-term capital liquidity.

Using a growth accounting approach with country level data, Abdel-Wahab and Vogl (2011) compared Germany, France, UK, USA and Japan construction sectors over the period 19902005. These analyses suggested that this sector growth lags behind the growth in all industries, with Germany and Japan presenting negative growth rates in construction. Using a panel error correction model, Liu and London (2011a) found a causal link and a significant correlation between new housing supply and construction costs in the Australian sub-national housing construction markets. Liu and London (2013) used a vector error correction model with a dummy variable to identify the relationship between housing supply and monetary policy. The results showed that the monetary policy changes and global economic turmoil can significantly affect the supply side of the housing sector in Australia.

Interesting because of the resemblance to the Spanish case, is the study of You and Zi (2007), which analyzed the case of Korea in the late 1990s. The Korean construction sector was impacted by an economic crisis in November 1997. Using the data envelopment analysis (DEA) approach for the period 1996-2000, the author found leverage ratio, export weight, institutional ownership and asset size as factors impacting all efficiency measures. Other studies that should be emphasized in the construction field are Horta, Camanho and da Costa (2010) and El- 
Mashaleh, Rababeh and Hyari (2011), who used the DEA method to evaluate the safety efficiency of every contractor aiming to transform inefficient contractors into high efficiency contractors.

\section{Stochastic Frontier Analysis Strategy to Measure Technical Efficiency}

In order to measure company-specific efficiency, we apply the Battese and Coelli (1995) model ${ }^{2}$. In this model, the function which explains inefficiency is estimated as a single step with production technology, which avoids the problem of inconsistency of a two-stage estimation process. Wang and Schmidt (2002) have cautioned against the two-step procedure to calculate the effect of the measured covariates, the ' $z$ 's', on estimates, arguing that the omission of the covariates at the 'first step' is tantamount to the omitted variable problem in ordinary regression. Nonetheless, this procedure is common and, indeed, is routine in the DEA literature.

The starting point was the model proposed by Battese and Coelli in 1995 (hereinafter BC95). In the BC95 model firm effects are assumed to be distributed as truncated normal random and are allowed to vary systematically with time. The BC95 production function can be expressed as:

$Y_{i t}=\beta_{o}+\sum_{j=1}^{k} \beta_{j} X_{j i t}+\left(V_{i t}-U_{i t}\right) \quad, i=1, \ldots, N, t=1, \ldots, T$,

where $0<U_{i t}<1$.

In (3.1), $Y_{i t}$ denotes (the logarithm) of production of the $\mathrm{i}$-th company in the $\mathrm{t}$-th period; $X_{j i t}$ represents the k-th (transformation) of input quantities; $\beta_{j}$ represents the output elasticity with respect to the j-th input; $V_{i t}$ is a random variable assumed to be iid $N\left(0, \sigma_{v}^{2}\right)$ and independently distributed of $U_{i t}$, which has the following specification:

$U_{i t}=z_{i t} \delta+W_{i t}$

In (3.2), $x_{i}$ is a $(1 \mathrm{x} \mathrm{m})$ vector of explanatory variables associated with the technical inefficiency of production of firms over time. The explanatory variables may include some input variables in the stochastic frontier, provided the inefficiency effects are stochastic. If the first z-variable is one and the coefficients of all other $z$ variables are zero, then this case represents the model specified in Stevenson (1980) and Battese and Coelli (1992).

In (3.2), $\delta$ is a ( $\mathrm{mx} 1)$ vector of unknown coefficients. If all elements of the $\delta$ vector are zero, then the technical inefficiency effects are not related to the $z$ variables and the half-normal distribution originally specified in Aigner, Lovell and Schmidt (1977) is obtained.

In (3.2), $W_{i t}$ is a random variable $N\left(0, \sigma^{2}\right)$, but is not necessarily identically distributed. The $U_{i t} s$ and the $W_{i t} s$ are independently distributed for all $\mathrm{t}=1,2, \ldots, \mathrm{T}$, and $i=l, 2, \ldots, N$.

In (3.2), $U_{i t}$ is a non-negative truncation of the $N\left(\Upsilon_{i t} \delta, \sigma^{2}\right)$ distribution, $z_{i t} \delta$ being the average of the normal distribution, which is truncated to zero to obtain the distribution of $U_{i r}$. The fact that $U_{i t}$ is non-negative does not mean that it has to be positive for each observation.

In the BC95 model, the authors use the parameterization of Battese and Corra (1977) where $\sigma_{V}^{2}$ and $\sigma_{u}^{2}$ are substituted by $\sigma^{2}={\sigma_{V}}^{2}+\sigma_{\mu}{ }^{2}$ and $\gamma=\sigma_{\mu}{ }^{2} /\left(\sigma_{V}{ }^{2}+\sigma_{\mu}{ }^{2}\right)$. Thus, $\gamma$ parameter must lie between 0 and 1 .

\footnotetext{
2 See Coelli (2005) for an in-depth explanation of the model and Olsen and Henningsen (2011) for the right interpretation of marginal effects of the z's variables on technical efficiency when estimating the translog production function.
} 
The TE of production for the i-th firm in the $\mathrm{t}$-th observation is defined by the equation: $\mathrm{TE}_{i,}=$ $\exp \left(-U_{i t}\right)=\exp \left(-\tau_{i t} \delta-W_{i p}\right)$. The maximum likelihood method is used for the simultaneous estimation of the parameters of the BC95 model.

\section{Data and Empirical Specification ${ }^{3}$}

The SABI (Sistema de Análisis de Balances Ibericos) database, managed by Bureau van Dijk provides the necessary data to estimate a TE measure. The study sample includes 692 firms belonging to the category of firms in Real Estate development, Construction of residential buildings and Construction of non-residential buildings (NACE Rev. 2 codes 4110, 4121 and 4122). The data were collected by SABI from the annual accounts filed with the Companies Register. The database is a balanced panel observed over the period 1996-2011. This panel displays information on the input used by each company in different years, representing the output produced as VA (Added Value in real terms). The capital factor of each company (defined as the market value of assets owned by the firms, in constant prices) is called Capital $(K)$. The number of workers is referred to as Labour (L). Finally, factor representing intermediate consumption (raw materials and part-finished products and services) is called CI.

In the first step we estimate the average TE of the period and its time behavior. In the second step, in order to analyze the effect of the housing cycle, we will estimate the variables affecting TE by dividing the sample period into two sub-periods: 1996-2007, before the Burst of the Housing Bubble (hereinafter pre-BHB); and 2007-2011, after the Burst of the Housing Bubble (hereinafter post-BHB). Table 1 presents a summary statistics of the data in both periods.

Table 1: Summary statistics

\begin{tabular}{|c|c|c|c|c|c|c|}
\hline No. of firms & $\begin{array}{c}\text { No. of } \\
\text { observations }\end{array}$ & Variable & Mean & $\begin{array}{c}\text { Standard } \\
\text { Deviation }\end{array}$ & $\begin{array}{l}\text { Minimum } \\
\text { Value }\end{array}$ & $\begin{array}{r}\text { Maximum } \\
\text { Value }\end{array}$ \\
\hline \multicolumn{7}{|c|}{ Pre- BHB (1996-2007) } \\
\hline \multirow[t]{4}{*}{692} & 8,304 & $V A$ & $1,033.50$ & $12,909.06$ & 112.3 & $365,321.50$ \\
\hline & & $L$ & 84.68 & 266.28 & 2 & 7,245 \\
\hline & & $K$ & 1321.83 & $5,410.70$ & 0.16 & $157,285.84$ \\
\hline & & $C I$ & $9,534.80$ & $50,645.56$ & 2.3 & $1,443,313.00$ \\
\hline \multicolumn{7}{|c|}{ Post- BHB (2007-2011) } \\
\hline \multirow[t]{4}{*}{692} & 2,768 & $V A$ & 905.40 & $18,780.39$ & 7.8 & $429,711.40$ \\
\hline & & $L$ & 95.66 & 378.00 & 1 & 7,633 \\
\hline & & $K$ & 1744.51 & 7229.697 & 0.7 & $154,973.86$ \\
\hline & & $C I$ & $11,655.10$ & $57,094.15$ & 1.3 & $1,354,720.00$ \\
\hline
\end{tabular}

Notes: Output (VA), capital (K) and Intermediate Consumptions (IC) are in thousands of euros.

Variables VA, K and CI are deflated using the implicit deflator index of the construction GFCF. Prices used to deflate output and inputs are obtained from the Spanish Statistical Office (various years).

\footnotetext{
${ }^{3}$ Regarding the choice of the sample, the criterion followed has been the availability of comprehensive data of the Amadeus database. We have selected those firms in the Amadeus database reporting data for all years in order to have a balanced panel data.
} 


\section{SFA Estimation}

In order to estimate the production function from which to obtain efficiency scores, we take as a starting point the translog specification (hereafter translog). The translog function is a more flexible extension of the Cobb-Douglas function, therefore does not require a constant and unitary elasticity of substitution. Hence, the translog function can be seen as a combination of the Cobb-Douglas function and the quadratic function. To check whether the Cobb-Douglas production function is rejected in favor of the translog production function, we will apply a likelihood ratio test.

The translog production function has following specification of the stochastic frontier model:

$$
\begin{aligned}
& \ln y_{i t}=\beta_{0}+\beta_{1} \ln X_{1 i t}+\beta_{2} \ln X_{2 i t}+\beta_{3} \ln X_{3 i t}+\frac{1}{2} \beta_{11}\left(\ln X_{1 i t}\right)^{2}+ \\
& \frac{1}{2} \beta_{22}\left(\ln X_{2 i t}\right)^{2}+\frac{1}{2} \beta_{33}\left(\ln X_{3 i t}\right)^{2}+\beta_{12} \ln X_{1 i t} \ln X_{2 i t}+\beta_{13} \ln X_{1 i t} \ln X_{3 i t}+ \\
& \beta_{23} \ln X_{2 i t} \ln X_{3 i t}+\tau_{1} t+\tau_{2} t^{2}+\left(v_{i t}-u_{i t}\right)
\end{aligned}
$$

Where

- The subscript "i" denotes the ith sample firm $\mathrm{i}=1,2, \ldots \mathrm{N}$

- The parameters $\beta_{k}$ and $\beta_{k k}$ with $\mathrm{k}=1,2,3$ are unknown parameters to be estimated.

- The subscript " $\mathrm{t}$ " indicates the $\mathrm{t}$-th year of the sample $\mathrm{t}=1996,2006$ for period 1996-2006.

- The variable ln $y_{i t}$ denotes the output produced by each firm "i" and year "t".

- Variables $X_{\text {kit }}$ with $\mathrm{k}=1,2,3$ are the explanatory variables of the model per year and per company.

- $\quad v_{i t}$ is a random error term assumed to be independently and identically distributed (iid) as $N\left(0, \sigma_{V}^{2}\right)$.

- $u_{i t}$ is a non-negative random variable which is assumed to account for technical inefficiency in production and are assumed to be iid as truncations at zero of the $N\left(\mu, \sigma_{\mu}^{2}\right)$

There is also the variable $t$ and $t^{2}$ which are a variables added here to measure the Hicks-neutral technical change.

In the estimation process, the estimation algorithm re-parameterizes the variance parameter of the noise term $\left(\sigma_{V}{ }^{2}\right)$ and the scale parameter of the inefficiency term $\left(\sigma_{\mu}{ }^{2}\right)$ and instead estimates the parameters $\sigma^{2}=\sigma_{V}{ }^{2}+\sigma_{\mu}{ }^{2}$ and $\gamma=\sigma_{\mu}{ }^{2} /\left(\sigma_{V}{ }^{2}+\sigma_{\mu}{ }^{2}\right)$. The parameter $\gamma$ lies between zero and one and indicates the importance of the inefficiency term. If $\gamma$ is zero, the inefficiency term $u$ is irrelevant and the results should be equal to OLS results. In contrast, if $\gamma$ is one, the noise term $v$ is irrelevant and all deviations from the production frontier are explained by technical inefficiency.

Table 2 displays the estimated coefficients for the period 1996-2011. To test the model, we conducted various hypothesis test of restriction on the parameters of the production structure. Decision is made based on the generalized likelihood-ratio statistic (the t-test for the coefficient $\gamma$ is not valid, because $\gamma$ is bound to the interval $[0,1]$ and hence, cannot follow a t-distribution). The hypothesis test along with the decision is reported in Table 2. 
Table 2 Estimations ${ }^{4}$ and tests of hypothesis

\begin{tabular}{|c|c|c|c|c|}
\hline \multirow[b]{2}{*}{ Variable } & \multicolumn{4}{|c|}{ Maximum-likelihood estimates } \\
\hline & & Coeffic. & Std Error & \\
\hline Constant & & 7.1334 & $(0.013)^{* * *}$ & \\
\hline Capital & & 0.1378 & $(0.002)^{* * *}$ & \\
\hline Labor & & 0.5204 & $(0.006)^{* * *}$ & \\
\hline$I C$ & & 0.3340 & $(0.003)^{* * *}$ & \\
\hline Time & & -0.0070 & $(0.004)$ & \\
\hline Capital $^{2}$ & & 0.0539 & $(0.002)^{* * *}$ & \\
\hline Labor $^{2}$ & & 0.3025 & $(0.010)^{* * *}$ & \\
\hline$I C^{2}$ & & 0.1470 & $(0.003)^{* * *}$ & \\
\hline Time $^{2}$ & & 0.0008 & $(0.000)$ & \\
\hline Capital*Labor & & -0.0455 & $(0.003)^{* * *}$ & \\
\hline IC*Capital & & -0.0066 & $(0.002)^{* *}$ & \\
\hline Labor*IC & & -0.1800 & $(0.005) * * *$ & \\
\hline$\sigma^{2}=\sigma_{V}^{2}+\sigma_{\mu}^{2}$ & & 1.3710 & $(0.253) * * *$ & \\
\hline$\gamma$ & & 0.9085 & $(0.017)^{* * *}$ & \\
\hline Log (likelihood) & & -5266.67 & & \\
\hline \multicolumn{5}{|c|}{ Test of hypothesis for parameters } \\
\hline Test & Null hypothesis & Assumptions & $\chi^{2}$-statistics & Decision \\
\hline Stochastic Effect & $\gamma=0$ & Stochastic Effect & $(27537)^{* * *}$ & Reject $\mathrm{H}_{0}$ \\
\hline Cobb Douglas & $\beta_{6-12}=0$ & Translog & $(2874)^{* * *}$ & Reject $\mathrm{H}_{0}$ \\
\hline Returns to Scale & $\beta_{1-3}=1$ & $\begin{array}{l}\text { Constant Returns to } \\
\text { Scale }\end{array}$ & $(2.3)$ & Accept $\mathrm{H}_{0}$ \\
\hline
\end{tabular}

The Cobb Douglas specification is rejected in favor of the Translog specification. The null hypothesis, $\mathrm{H}_{0}: \gamma=0$, is also rejected confirming that the Stochastic production function is an adequate specification.

The first order parameters in Table 2 can be identified as production elasticities evaluated at the sample means, since all data were corrected by geometric mean before the estimation of the model. Looking at the elasticity of scale, the results show that the sum of the parameters $\beta_{1}, \beta_{2}$ and $\beta_{3}$ are significantly different from 1 and, as a consequence, the construction sector presents decreasing returns to scale with a parameter 0.99. Hence, if all firms increase all input quantities by $1 \%$, the output quantity will usually increase by around $0.99 \%$.

The coefficient of time (year of observation) and its square $\left(t_{i m e}{ }^{2}\right)$ are not significant therefore technical progress in Hicks sense cannot be confirmed.

Due to $\gamma=0.90$, we conclude that inefficiency is more important than noise for explaining deviations from the production. However, parameter $\gamma$ cannot be interpreted as the proportion of the total variance that is due to inefficiency.

\footnotetext{
${ }^{4}$ All maximum likelihood estimates of the models are obtained by using the software $\mathrm{R}$ version 3.0.3, Frontier package made by Coelli, T. and Arne Henningsen (2013)
} 
As neither the noise term $v_{i t}$ nor the inefficiency term $u_{i t}$ but only the total error term $\varepsilon_{i t}=$ $v_{i t}-u_{i t}$ is known, the technical efficiencies $\mathrm{TE}_{i t}=e^{-w_{i t}}$ are generally unknown. However, given that the parameter estimates (including the parameters $\sigma^{2}$ and $\gamma$ or $\sigma_{V}{ }^{2}$ and $\sigma_{u}{ }^{2}$ ) and the total error term $\varepsilon_{\mathrm{it}}$ are known, it is possible to determine the expected value of the TE (Coelli, 2005):

$$
\overline{\mathrm{T}}_{i t}=E\left[e^{\mathrm{w}_{\mathrm{it}}}\right]
$$

Results show that the average score of TE for the Spanish construction industry is 0.85 . Figure 2 shows the performance of the TE during the 1996-2011 period. A growing tendency in the TE of the Spanish construction sector was observed between 1996 to 2003 with peaks in 1999 and 2003. From 2003 to 2011 the sector TE shows a steady decrease of some $8 \%$ in total.

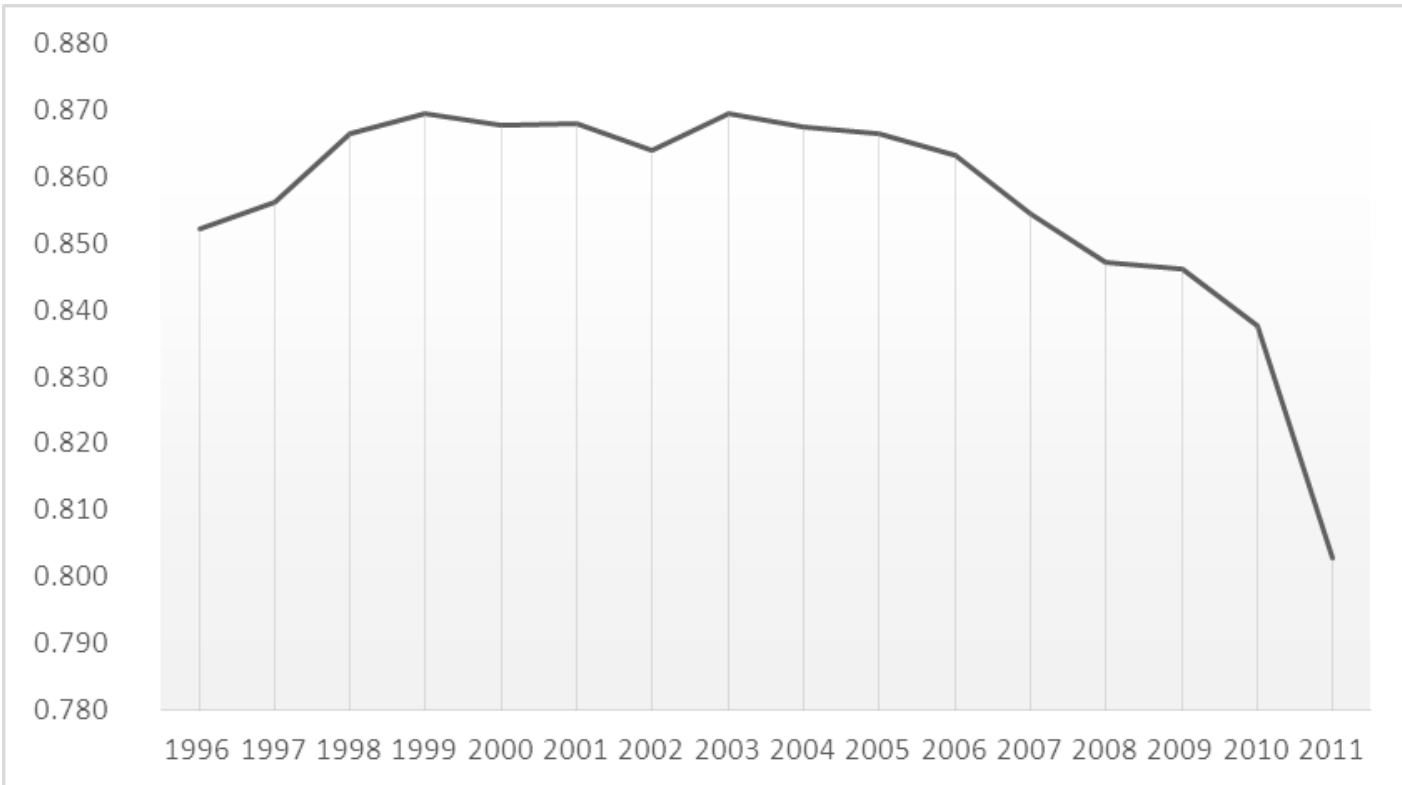

Figure 2: Evolution of TE period 1996-2011.

\section{Factors Affecting Efficiency}

As explained above, we will use the BC95 model to investigated factors and others random effects affecting the TE. With the assumptions developed in section 3 in place, the parametric mean of the density function, $\mu_{i t}$, can be specified as

$\mu_{i t}=\delta_{0}+\delta_{1}$ Age $_{i t}+\delta_{2}$ Size $_{i t}+\delta_{3}$ IntExp $_{i t}+\delta_{4}$ Debt Ratio $_{i t}+\delta_{5}$ Export $_{i t}+$
$\delta_{6}$ Diversification $_{i t}+\delta_{7}$ PublicSR $_{i t}+\delta_{8}$ StockMarket $_{i t}+\delta_{8}$ Mortg Const $_{i t}+W_{i t}$

It is important to mention that the BC95 model discussed in section 3 is only useful when the inefficiency effects $(\delta)$ are stochastic and follow a specific distribution.

Table 4 shows the definition and the expected signs of the explanatory variables of the sector TE. The expected sign of the $\delta$-parameters in the inefficiency model are not clear in all cases. The Older firms could be expected to have more experience and hence have less inefficiency. 
However Older firms are also likely to be more accommodate and thereby perhaps more inefficient.

Table 4: List of explanatory variables

\begin{tabular}{|c|c|c|c|}
\hline Variable & Type & Measurement & Expected sign \\
\hline Age & Value & Logarithm of age of the company each year & Positive/Negative \\
\hline Size & Value & $\begin{array}{l}\text { Logarithm of number of subsidiaries company } \\
\text { have }\end{array}$ & Positive/Negative \\
\hline IntExp & Value & Logarithm of Interest Expense Ratio & Positive \\
\hline Debt Ratio & Value & Logarithm of debt Ratio each year & Positive \\
\hline Export & Dummy & $1=$ Expor, $0=$ Otherwise & Negative \\
\hline Diversification & Dummy & $1=$ Diversified, $0=$ Otherwise & Negative \\
\hline PublicsR & Dummy & $1=$ Public Staff Remun, $0=$ Otherwise & Negative \\
\hline StockMarket & Dummy & $1=$ Publicly Traded, $0=$ Otherwise & Negative \\
\hline Mortg Const & Value & \multicolumn{2}{|c|}{ Logarithm of number of mortgages constituted each year } \\
\hline
\end{tabular}

Source: Prepared by the authors

The Interest-Expense ratio intimates the amount of gross income that is being spent to pay the interest on borrowed money. Interest-Expense Ratio is a measurement of financial efficiency and is determined based on information derived from a business' operations financial statements. We therefore expect that a high value of this variable to be associated with a high inefficiency level.

You and $\mathrm{Zi} \mathrm{(2007)} \mathrm{argued} \mathrm{that} \mathrm{there} \mathrm{are} \mathrm{some} \mathrm{conflicting} \mathrm{theories} \mathrm{on} \mathrm{the} \mathrm{relationship} \mathrm{between}$ corporate leverage and efficiency. However, the Spanish construction firms had been heavily indebted, and suffered from severe financial imbalance. We expect leverage to have a negative effect on sector efficiency and therefore high Debt Ratio influences inefficiency positively.

Export and Diversification may be viewed as a market strategy. Economists suggest the reinsurance effect hypothesis that a firm's diversification reduces its profit variability through a business portfolio effect, and thus increases its value (Lewellen, 1971). We expect productive diversification to have a positive effect on sector efficiency.

PublicSR and StockMarket are variables related to corporate transparency. Listed companies are required to provide additional retirement information. Shareholders will have a better understanding of the real situation of the company and will act accordingly. For this reason, we consider that a listed company should be associated with less technical inefficiency. We use the same argument of transparency for companies that report board of directors' remuneration.

Finally, Mortg Const is a demand variable indicating the number of mortgages constituted each year. As mentioned before, construction is a cyclically sensitive activity. We include this variable to see the impact that housing cycles caused to the efficiency of the Spanish construction sector.

We estimate the BC95 model for both periods, pre-BHB (1996-2007) and post-BHB (20082011). Table 5 shows the variables included as z's variables to model the mean of the inefficiency term, and the expected signs. $\gamma$ and $\sigma^{2}$ components are statistically significant in both periods. Likewise, in both periods the $\gamma$ coefficient indicates that inefficiency is more important than noise for explaining deviations from the production. In the pre-BHB period, seven out of the nine covariates are found to be significant (five out of nine in the post-BHB period). 
We look at the sense of the signs because the size of the coefficients of the BC95 model $(\delta)$ cannot be reasonably interpreted ${ }^{5}$. Age and Size variables are negative in both periods (Age is not significant in the 2007-2011 period), which means that the older and bigger the firms are, the less inefficient they will be. As expected, the greater the degree of interest paid, the more inefficient construction companies are. It can therefore be concluded that financial efficiency is associated with TE for this sector. In contrast, PublicSR and StockMarket are not statistically significant as determinant of the inefficiency mean. Therefore we cannot confirm that to be a corporate transparent firm (at least as defined in this study) is correlated to a lower inefficiency level.

Table 5: TE Effects Frontier for period 1996-2007 and period 2008-2011.

\begin{tabular}{|c|c|c|c|c|c|c|c|}
\hline \multicolumn{4}{|c|}{ Technical Efficiency Effects Frontier (period 1996-2007) } & \multicolumn{4}{|c|}{ Technical Efficiency Effects Frontier (period 2008-2011) } \\
\hline Variable & Coefficient & Std Error & Expected & Variable & Coefficient & Std Error & Expected \\
\hline Age & -1.7605 & $(0.405)^{* * *}$ & $\sqrt{ }$ & Age & -1.1572 & $(0.723)$ & $\sqrt{ }$ \\
\hline Size & -0.2332 & $(0.075)^{* *}$ & $\sqrt{ }$ & Size & -1.0311 & $(0.346)^{* *}$ & $\sqrt{ }$ \\
\hline IntExp & 1.6871 & $(0.311)^{* * *}$ & $\sqrt{ }$ & IntExp & 1.8583 & $(0.418)^{* * *}$ & $\sqrt{ }$ \\
\hline Debt Ratio & -0.0488 & $(0.002)^{* * *}$ & $\mathrm{X}$ & Debt Ratio & 1.5516 & $(0.380)^{* * *}$ & $\sqrt{ }$ \\
\hline Export & 1.6419 & $(0.328)^{* * *}$ & $\mathrm{X}$ & Export & -0.6534 & $(0.387)^{\cdot \cdot}$ & $\sqrt{ }$ \\
\hline Diversification & 0.3022 & $(0.106)^{* *}$ & $\mathrm{X}$ & Diversification & -0.5900 & $(0.413)$ & $\sqrt{ }$ \\
\hline PublicsR & -0.0696 & $(0.132)$ & $\sqrt{ }$ & PublicsR & -0.1541 & $(0.262)$ & $\sqrt{ }$ \\
\hline StockMarket & -0.9752 & (1.581) & $\sqrt{ }$ & StockMarket & 0.9374 & $(0.608)$ & $\mathrm{X}$ \\
\hline Mortg Const & 0.5100 & $(0.195)^{* *}$ & & Mortg Const & -0.3212 & $(0.115)^{* *}$ & \\
\hline Constant & -1.2521 & $(0.938)$ & & Constant & 4.5640 & $(1.589)^{* *}$ & \\
\hline$\sigma^{2}=\sigma_{V}^{2}+\sigma_{\mu}^{2}$ & 0.8562 & $(0.103)^{* * *}$ & & $\overline{\sigma^{2}}=\sigma_{V}^{2}+\sigma_{\mu}^{2}$ & 1.6314 & $(0.412)^{* * *}$ & \\
\hline$\gamma$ & 0.8520 & $(0.018)^{* * *}$ & & $\gamma$ & 0.9320 & $(0.017)^{* * *}$ & \\
\hline
\end{tabular}

Source: Prepared by the authors

Export, Diversification and Debt Ratio behaves as expected in the post-BHB period (2008-11), but opposite to that expected in the pre-crisis period. Intuitively we might think that, for the Export variable, during the formation of the housing bubble, domestic markets generate greater returns to investment than foreign markets and after the burst of housing bubble, foreign markets become more attractive (we can reason similarly for Diversification).

Debt Ratio behaviour could be associated with the patterns of the financial system. According to Akin et al. (2014) Banks' lending standards were softer in the real estate boom cycle ${ }^{6}$ than in the bust period. We believe that the pre-BHB (post-BHB) flexible (rigid) lending standards affect the negative (positive) relationship between the level of external debt and the inefficiency. Prudential policy measures limiting the credit institutions' incentives to take on excessive risk-taking could benefit the sector efficiency in expansive cycles. On the other hand, the on-going reforms aimed at strengthening financial stability should positively impact the construction sector efficiency ${ }^{7}$.

\footnotetext{
${ }^{5}$ Marginal effects of the variables that should explain the efficiency level on the efficiency estimates can be calculate following Olsen and Henningsen, (2011).

${ }^{6}$ Crotty (2008) advise that, in the boom period, "the risk taken has been so widespread and leverage has become so high that a symmetric crisis is not out of the question"

${ }^{7}$ Royal Decree Law 4/2014 establishing urgent measures to expedite and streamline corporate refinancing and debt restructuring processes. In essence, these measures aim at ensuring the survival of companies that, notwithstanding the accumulation of excessive financial burden, are viable from an operational point of view through an orderly and balanced system of agreements with creditors and a wider range of refinancing options.
} 
Mortg Const variable. The short term supply is inelastic in the construction sector therefore increases in demand produce rapid increases in prices. In a real estate growth cycle, large increases in mortgage activity would damage the efficiency of the sector. In contrast, increases in recessive periods would improve the efficiency of the sector. This variable has crucial implications for public policy. Policies promoting mortgage activity (e.g. incentives promoting home ownership) should be carried out only in real estate recessive periods. However, as Pérez Barrasa el al. (2011) note, tax incentives to promote home ownership have always existed over the past few decades and sometimes have even encouraged the purchase of a holiday house.

\section{Conclusion}

The Spanish construction sector enjoyed a period of constant growth and played an important role in the development of the Spanish economy over the past several decades. However, the burst of the Spanish Housing Bubble in 2007 resulted in unprecedented hardships for the construction sector.

This study estimates TE of the firms under the three sectors related to Spanish construction activity before and after the Burst of the Real Estate Bubble. The empirical application used accountancy data from 692 construction firms in the period 1996-2011. Our paper contributes to the literature by estimating the impact of the financial crisis in the efficiency of the construction sector. Furthermore, to the best of our knowledge, this study is the first to estimate the TE of the Spanish construction sector using SFA. This research found, as its main conclusion, that the average Technical Efficiency of the Spanish construction sector is 0.85 in the period 1996-2011. From 2003 to 2011 the sector TE shows a steady decrease of some $8 \%$ in total. The results highlight that the study of factors affecting Technical Efficiency in the construction sector must be analyzed as dependent on real estate cycles.

We also identify several important factors affecting efficiency change. Firstly, it was found that to be an exporting company impacts technical efficiency negatively/positively in expansive/recessive real estate markets. Secondly to be a diversified company impacts technical efficiency negatively/positively in expansive/recessive real estate markets. Thirdly, an increase in the level of external debt will impact technical efficiency positively/negatively in recessive/expansive real estate markets. Fourthly, an increase in mortgage activity will impact technical efficiency positively/negatively in recessive/expansive real estate markets. Fifth, the age and the size always have positive effects in the technical efficiency of construction companies. Sixthly, construction companies with high financial expenses are more inefficient than those with lower financial expenses.

Our results are meaningful to policymakers. The above findings are significant in terms of promoting business concentration in the sector. The findings are also significant in terms of promoting counter-cyclical policies to the sector. Furthermore policies promoting diversification and exports will benefit efficiency in sector recessionary cycle.

Financial assistance to the companies that are viable from an operational point of view is in accordance with the actual sector stage. Additionally, prudential policy measures limiting the credit institutions' incentives to take on excessive risk-taking could benefit the sector efficiency in expansive cycles. Monetary and regulatory policies impacting mortgage activity will improve the sector efficiency in real state recessive cycle and will damage it in expansive cycle.

This is the main recommendation of this research in terms of policy. Furthermore, the research gave rise to three recommendations for construction companies. The first is to take note of the benefits that cooperation and concentration provide to business efficiency. A second recommendation is that the accumulation of excessive financial burden damages the business 
long-term stability. A final recommendation is to adjust the business strategy to the economic prospects.

\section{References}

Abdel-Wahab, M. and Vogl, B., 2011. Trends of productivity growth in the construction industry across Europe, US and Japan. Construction Management and Economics, 29(6), pp. 635-44. doi:

http://dx.doi.org/10.1080/01446193.2011.573568

Aigner, D., Lovell, C.A.K. and Schmidt, P., 1977. Formulation and estimation of stochastic frontier production function models. Journal of Econometrics, 6(1), pp.21-37. doi:

http://dx.doi.org/10.1016/0304-4076(77)90052-5

Akin, O.J., Garcia Montalvo, J., Garcia Villar, J.L., Peydró and Raya, J.M., 2014. The real estate and credit bubble: Evidence from Spain. Available at: http://hdl.handle.net/10230/22625.

Banker, R.D., Charnes, A. and Cooper, W.W., 1984. Some Models for Estimating Technical and Scale Inefficiencies in Data Envelopment Analysis. Management Science, 30(9), pp.1078-92. doi:

http://dx.doi.org/10.1287/mnsc.30.9.1078

Battese, G.E. and Coelli, T.J., 1992. Frontier production functions, technical efficiency and panel data: With application to paddy farmers in India. Journal of Productivity Analysis, 3(1-2), pp.153-69. doi:

http://dx.doi.org/10.1007/BF00158774

Battese, G.E. and Coelli, T.J., 1995. A model for technical inefficiency effects in a stochastic frontier production function for panel data. Empirical Economics, 20(2), pp.325-32. doi:

http://dx.doi.org/10.1007/BF01205442

Battese, G.E. and G. Corra., 1977. Estimation of a Production Frontier Model: With Application to the Pastoral Zone of Eastern Australia. Australian Journal of Agricultural Economics, 21(1), pp.167-79.

Charnes, A., Cooper, W.W. and Rhodes, E., 1978. Measuring the efficiency of decision making units. European Journal of Operational Research, 2(6), pp.429-44. doi:

http://dx.doi.org/10.1016/0377-2217(78)90138-8

Chau, K.W. and Wang, Y.S., 2003. Factors Affecting the Productive Efficiency of Construction Firms in Hong Kong. In: CIB TG 23 International Conference. Hong Kong.

Coelli, T. and Henningsen, A., 2013. Frontier: Stochastic Frontier Analysis. R package version 1.0. Available at: http:/ /CRAN.R-Project.org/package=frontier.

Coelli, T., 2005. An introduction to efficiency and productivity analysis. Springer Science and Business Media.

Edvarsen, D.F., 2004. Efficiency of Norwegian Construction Firms In Four Essays in the Measurement of Production Efficiency. PhD. Goterborg University.

El-Mashaleh, M.S., Rababeh, S.M. and Hyari, K.H., 2010. Utilizing data envelopment analysis to benchmark safety performance of construction contractors. International Journal of Project Management, 28(1), pp.61-7. doi:

http://dx.doi.org/10.1016/i.ipproman.2009.04.002

Eurostat. [online] Available at: http://epp.eurostat.ec.europa.eu/portal/page/portal/eurostat/home/

Farrell, M.J., 1957. The Measurement of Productive Efficiency. Journal of the Royal Statistical Society Series A (General), 120(3), pp.253-90. doi:

http://dx.doi.org/10.2307/2343100

Gimeno, R. and Martinez-Carrascal, C., 2010. The relationship between house prices and house purchase loans: The Spanish case, Journal of Banking \& Finance, 34(8), pp.1848-55. doi:

http://dx.doi.org/10.1016/i.jbankfin.2009.12.011

Greene, W., 2005a. Fixed and random effects in stochastic frontier models. Journal of Productivity Analysis, 23(1), pp.7-32. doi: http://dx.doi.org/10.1007/s11123-004-8545-1

Greene, W., 2005b. Reconsidering heterogeneity in panel data estimators of the stochastic frontier model. Journal of Econometrics, 126(2), pp.269-303. doi: http://dx.doi.org/10.1016/j.jeconom.2004.05.003

Horta, I. M., Camanho, A.S, and Moreira da Costa, J., 2012. Performance Assessment of Construction Companies: A Study of Factors Promoting Financial Soundness and Innovation in the Industry. International Journal of Production Economics, 137 (1), pp. 84-93. doi: http://dx.doi.org/10.1016/i.ijpe.2012.01.015

Horta, I.M., Camanho, A.S. and Da Costa, J.M., 2010. Performance assessment of construction companies integrating key performance indicators and data envelopment analysis. Journal of Construction Engineering and Management, 136(5), pp.581-94. doi: http://dx.doi.org/10.1061/(ASCE)CO.1943-7862.0000145

Horta, I.M., Camanho, A.S., Johnes, J. and Johnes, G., 2013. Performance trends in the construction industry worldwide: An overview of the turn of the century. Journal of Productivity Analysis, 39(1), pp.89-99. doi:

http://dx.doi.org/10.1007/s11123-012-0276-0

Kapelko, M., Oude Lansink, A. and Stefanou, S.E., 2014. Assessing dynamic inefficiency of the Spanish construction sector pre- and post-financial crisis. European Journal of Operational Research, 237(1), pp.349-57. 
doi: http://dx.doi.org/10.1016/j.ejor.2014.01.047

Kumbhakar, S.C., 1990. Production frontiers, panel data, and time-varying technical inefficiency. Journal of Econometrics, 46(1-2), pp.201-11. doi: http://dx.doi.org/10.1016/0304-4076(90)90055-X

Lee YH and P Schmidt (1993). "A Production Frontier Model with Flexible Temporal Variation in Technical Efficiency." in Fried HO and SS Schmidt (eds.) the Measurement of Productive Efficiency: Techniques and Applications, Oxford U.K.: 237-255.

Lewellen, W., 1971. A Pure Financial Rationale for the Conglomerate Merger. Journal of Finance. Papers and Proceedings of the Twenty-Ninth Annual Meeting of the American Finance Association Detroit, Michigan December 28-30, 1970. [May 1971]. 26(2), pp.521-37.

Li, J., Chiang, Y.H., Choi, T.N.Y. and Man, K.F., 2013. Determinants of efficiency of contractors in Hong Kong and China: Panel data model analysis. Journal of Construction Engineering and Management, 139(9), pp.1211-23. doi:

http://dx.doi.org/10.1061/(ASCE)CO.1943-7862.0000698

Liu, J., and London, K. (2011a). Analysing the relationship between new housing supply and residential construction costs with the regional heterogeneities. Australasian Journal of Construction Economics and Building, 11(3), pp.58-67.

doi: http://dx.doi.org/10.5130/ajceb.v11i3.2174

Liu, J., and London, K. (2013). Modelling housing supply and monetary policy within the context of global economic turbulence. International Journal of Strategic Property Management, 17(1), pp.1-20.

doi: http://dx.doi.org/10.3846/1648715X.2012.735273

Olsen, J.V. and Henningsen, A., 2011. Investment Utilization and Farm Efficiency in Danish Agriculture. FOI Working Paper No. 2011/13. Institute of Food and Resource Economics.

Orea, L. and Kumbhakar, S.C., 2004. Efficiency measurement using a latent class stochastic frontier model. Empirical Economics, 29(1), pp.169-83. doi: http://dx.doi.org/10.1007/s00181-003-0184-2

Pérez Barrasa, T., Rodríguez Coma, M. and Blanco Moreno, A., 2011. Política de Gasto en vivienda: España, 2010. Papeles de trabajo del Instituto de Estudios Fiscales. ISSN 1578-0252, No 1, 2011, pp.7-50.

Pilateris, P. and McCabe, B., 2003. Contractor financial evaluation model (CFEM). Canadian Journal of Civil Engineering, 30(3), pp.487-99. doi: http://dx.doi.org/10.1139/102-098

Pitt, M.M. and Lee, L., 1981. The measurement and sources of technical inefficiency in the Indonesian weaving industry. Journal of Development Economics, 9(1), pp.43-64. doi:

http://dx.doi.org/10.1016/0304-3878(81)90004-3

Ruggiero, J., 2004. Performance evaluation when non-discretionary factors correlate with technical efficiency. European Journal of Operational Research, 159(1), pp.250-57. doi:

http://dx.doi.org/10.1016/S0377-2217(03)00403-X

Ruggiero, J., 2007. A comparison of DEA and the stochastic frontier model using panel data. International Transactions in Operational Research, 14(3), pp.259-66. doi:

http://dx.doi.org/10.1111/j.1475-3995.2007.00585.x

Shiller, R. J., (2008). The subprime solution: How today's global financial crisis happened and what to do about it. Princeton, N.J: Princeton University Press.

Simar, L. and Zelenyuk, V., 2011. Stochastic FDH/DEA estimators for frontier analysis. Journal of Productivity Analysis, 36(1), pp.1-20. doi: http://dx.doi.org/10.1007/s11123-010-0170-6

Spanish Statistical Office. [online] Available at: http://www.ine.es/

Stevenson, R.E., 1980. Likelihood functions for generalized stochastic frontier estimation. Journal of Econometrics, 13(1), pp.57-66. doi: http://dx.doi.org/10.1016/0304-4076(80)90042-1

Sueyoshi, T. and Goto, M., 2009. DEA-DA for bankruptcy-based performance assessment: Misclassification analysis of Japanese construction industry. European Journal of Operational Research, 199(2), pp.576-94. doi: http://dx.doi.org/10.1016/j.ejor.2008.11.039

Tsolas, I.E., 2011. Modelling profitability and effectiveness of Greek-listed construction firms: An integrated DEA and ratio analysis. Construction Management and Economics, 29(8), pp.795-807. doi:

http://dx.doi.org/10.1080/01446193.2011.610330

Wang, H., and Schmidt, P., 2002. One-step and two-step estimation of the effects of exogenous variables on technical efficiency levels. Journal of Productivity Analysis, 18(2), pp.129-44. doi:

http://dx.doi.org/10.1023/A:1016565719882

You, T. and Zi, H., 2007. The economic crisis and efficiency change: Evidence from the Korean construction industry. Applied Economics, 39(14), pp.1833-42. doi: http://dx.doi.org/10.1080/00036840600690199

Zheng, X., Chau, K. and Hui, E.C.M., 2011. Efficiency assessment of listed real estate companies: An empirical study of China. International Journal of Strategic Property Management, 15(2), pp.91-104. doi:

http://dx.doi.org/10.3846/1648715X.2011.582739 